\title{
The Basic concept of Economic Education At the Level of Supra Structure and Inrastruktur Politics in Indonesia
}

\author{
Refika $^{1}$, Lias Hasibuan ${ }^{2}$, Kasful Anwar Us ${ }^{3}$ \\ ${ }^{1}$ Sekolah Tinggi Agama Islam Diniyah Pekanbaru, Riau, Indonesia \\ ${ }^{2}$ Universitas Islam Negeri Sultan Thaha Saifuddin Jambi, Jambi, Indonesia \\ ${ }^{3}$ Universitas Islam Negeri Sultan Thaha Saifuddin Jambi, Jambi, Indonesia \\ * Corresponding author: \\ Email: refikaaja87@gmail.com
}

\begin{abstract}
.
This article aims to get an overview of how basic concepts of economics of education at the level of the supra-structure and infra-political structure in Indonesia. In that state of supra structure that includes the legislative, executive, judicial, and other state institutions, the government of Indonesia has made a policy in writing that stated in the mandate of the constitution the Constitution of 1945 of the State's obligation in financing education in Indonesia. Education funding is contained in Article 31 paragraph (4) of the 1945 Constitution that the State prioritize the education budget by $20 \%$ from $A P B N / A P B D$. If seen in a state of infra-structure that covers the center of the political power of the people, contained in elements of social organization, political figures, community leaders, the tools of political communication, and especially a political organization or political party is able to affect the workings of the apparatus of the public to express, distribute, translate, convert demands, support and the specific problems associated with the public interest, especially in this case the education sector, the government has given freedom in expressing their opinions. It is proved that the Indonesian State has been attempted in the give attention to education for its citizens. Because with a quality education will be able to improve economic growth and development in a Country. However, the education budget by $20 \%$ is considered not able to maximize the improvement of the quality of education in Indonesia, so the need for a new policy in increasing the percentage of the budget for education.
\end{abstract}

Keywords: Economic Education, Supra-Structure, Infra-Structure, Political

\section{INTRODUCTION}

In view of the Regulations of the most high in Indonesia, namely the 1945 Constitution in paragraph four which reads: a government of the state of Indonesia that protect the whole Indonesian nation and the entire country of Indonesia and to promote the general welfare, the intellectual life of the nation, and participate implement world order based on Independence, eternal peace and social justice.

From the fragment of the paragraph the fourth such since the time of the declaration of independence by IR. Sukarno and Hatta, Indonesia is already aspiring to increase the intelligence of the nation. After the 1945 Constitution amended, then the 
Chapter XIII is converted into Culture and Education and consists of two articles, namely article 31 on education and article 32 about the culture.

This amendment gives the basic settings about the rights and obligations of the get the education that must be met by the state to its citizens. The contents of the article 31 is amended as follows: 1) Every citizen entitled to get education. 2)Every citizen is obliged to follow basic education and the government is obliged to finance it. 3) the Government shall establish and conduct a national education system that increases the faith and piety and noble character in the context of the intellectual life of the nation, which is governed by laws. 4) State budget prioritizes education to at least twenty percent of the budget revenue and expenditure as well as revenue and expenditure budget to meet the needs of national education. 5) the Government shall advance science and technology by upholding religious values and national unity for the progress of civilization and welfare of mankind.

The obligation of the State to finance education for each of its citizens embodied in the constitutional mandate the Constitution of 1945, in article 31 of the 1945 Constitution amendments explained: " (1) Every citizen has the right to education, (2) Every citizen is obliged to follow basic education and the government is obliged to finance it.". Based on the article 31 of this Country has two obligations, namely: education for every citizen and pay for education for every wargan his country. Education means the State must provide a place/ school, education, facilities and infrastructure, so that the teaching and learning activities can run. Finance the education that the State should provide funds / budget for the activities of teaching and learning that involves the educator, the school, facilities and infrastructure can be resolved.

\section{LITERATURE REVIEW}

\section{The Concept Of A Basic Economic Education}

Economic education is a blend of the two concepts are aligned, namely the economy and education. Economics as a science has been studying various human step in to fulfill all your desires with limited resources. Principle in the study of economics is efficiency, so that whatever activity is followed by the expenditure of funds must have great benefits. Thus the study of economic welfare-oriented, he lived the high society all his life. Given the studies of society, then who perceives the welfare of not only entrepreneurs, but also the consumers (users of the results of production). Economic growth largely determines the welfare of the community in material terms. So it takes the seriousness of the government in an effort to improve economic growth in the country.

In the perspective of investment in human resources (human capital), the basic concepts of economics of education considers the importance of the link between education, productivity and economic growth. Human capital assumes that labor is the holder of a capital, which is reflected in the skills, knowledge and productivity. 
User groups the results of production is the main source of the manufacturers in trying to improve their business, so this group should be maintained its existence (ability to buy it). If the ability to buy community does not exist, then it will affect the business world (roll mat).

Education is the conscious effort of man to prepare the humans have the ability to play an active role in shaping the future. Education according to the law of the republic of indonesian No.20 Year 2003 is a conscious and planned effort to create an atmosphere of learning and the learning process so that learners are actively developing the potential for him to have the strength of spiritual religion, self-control, personality, intelligence, noble character, and skills needed him, society, nation and state. While the goal of national education is the intellectual life of the nation and developing the Indonesian people fully. In the formulation of education according to the ACT contains the meaning that is deep and broad, associated with human resources, so it needs to be a serious, careful, comprehensive, strategic and responsible. It is necessary for the budget that is not little, careful planning and accountability are transparent.

The basic concepts that need to be considered in the development of education as a means of formation of professional human, so it can boost economic growth in the future which are as follows:

1. Education is the formation of human potential so that funds are disbursed to the world of education is an investment (capital investment human resources).

2. Education is the main function in the growth of the economy, and vice versa, so these two factors cannot be separated.

3. In the future will be a lot of diversity changes so that the necessary diversity in the world pendidikanbaik type, level and that stuff.

4. Naturally human beings are human beings all want to know so it needs a container that can cultivate a sense of desire for ignorance is education.

5. Internal factors education needs to accommodate factors eksteren that affect the linkages between the world of education denganpertumbuhan economy.

6. Budget allocation in education needs careful calculation, so that the accusations of bermanfaatan the world of education in the construction can be in the shots.

Development really refers to its function as a developer of human resources contribute in a very large fund. The funding requirements for the various levels of education and types of education may not be equated given the different purposes will require facilities and infrastructure as well as qualifications be different anyway, so leveling the budget for the difference in the level of education is considered less wise.

The form of the cost of the development of education including; regular Fees, Procurement of books, the Construction of physical facilities, Procurement of tools, labor and workshop, Procurement of instructional media, Procurement of personnel, increased Cost of human resources (personnel), either through training or further education. 
Problems always arise when laying down which component is the main. The magnitude of the costs for improving human resources in educational institutions often becomes the last priority. Whereas these components that most determine the direction and course of learning which are required is always to change at any time. When the state is has been growing, then the change in the community will be increased, so that the demanding world of education should make adjustments in order to meet the needs of the workforce that will be needed in the development process. These conditions clearly have an impact on the increased need for funds. If funding cannot be increased, then the world of education can not accelerate with the changes there. If the world of education is constant(the way place), because of the limitations of the budget, then the education will not be able to play a role in shaping graduates who can enter the labor market.

\section{Supra Structure and Infrastructure}

The target to be processed in economic policy is the structure of the economic life of the community, both individuals and groups in society. The economic structure of society can be classified into three, namely; the production process, distribution process and consumption process itself. However many people who argue that the distribution process including the production process, so that the structure of economic life consists of only two processes.

The production process in a broad sense (including the distribution process) is the process to create or increase the benefits (value) of goods or services needed by the community.

The process kosumsi which is a process to reduce (including to spend) the goods and services available in the community. That includes examples of the production process such as; eating rice, wearing clothes, using vehicles, occupy the house. The process of consumption of services or goods don't appear, such as transport and education occur simultaneously or in accordance with the process of kosumsinya.

The structure of economic life consists also of a structure that is both empirical and structure that are metaphysical (place of worship). Target economy is a structure that is empirical. In the process the structure of the life always used the principle of rational. To increase the success of needed another structure, namely the structure below (structure infra) and upper structure (the structure of the supra). The structure of the bottom serves to improve efficiency and effectiveness, while the structure above serves to increase the motivation of the business so that economic life can be done with a passion that high. So, better infra-structure and supra-structure is the capital that is invaluable. Capital or physical capital and a spiritual both need to be produced, maintained and always improved. If infrastructure such as roads, communication tools, the forest and the others, then the supra-structure in the form of philosophy, religion, belief, and the richness of other cultures.

3. Supra Structure and Infrastructure of the Political in Indonesia 
The success of political development in order to realize the ideals of the nation, can be seen from several indicators, as follows:

1. The quality of tranquility, security and peace that is felt by citizens in social life political, in the sense of not feeling oppressed, depressed and squeezed.

2. The level or quality of the regularity of social relations-economic rights are protected, obligations are regulated in a fair and better.

3. How much citizens participate, are invited to participate in the government.

4. The extent to which the political system is able to raise and lower the level of prosperity of society.

5. Whether the political system can stimulate the process of economic development or not.

In realizing the ideals of the nation at the level of central and local government, there are a number of institutions of the state as a supra political structure and infra-structure of politics. Supra political structure is the arrangement of government institutions at central and local that will run the life of the nation at once

realize what the expectations of the people. In addition, the infra-political structure can also be used as a transmitter of the aspirations and ideals of the people (the political makeup in the life of the community), such as political parties, the media, and the class of suppressors that can bridge the fulfillment of the expectations of society against the government.

The second element of the state structure, namely the supra-structure and infra structure is the traditional foods and shops-the centre of power of the state. The structure of the state is centered on the second element of the organizational structure of the country. Supra state structures is central to the formal power of the state. Formally, the power of the state in the sector of the supra structure centered on the state institutions or organs of the state such as: the legislative, executive, judicial, and other state institutions. While the infra structure of the country is the center of political power of the people. The political power of the people sector infrastructure (building below) contained in the elements of social organization, political figures, community leaders, the tools of political communication, and especially a political organization or a political party.

Almond and Coleman, distinguish the structure of the political infrastructure that consists of the political structure of the society, the atmosphere of the life of the political community and the political sector of society. As well as supra-political structure consists of the government sector, many government, and the political sector of government.

In the political life of democratic, political structure divided into two, namely formal and informal. The political structure of a formal nature is a political machine with a valid identify any problems, determine and implement all the decisions that have binding force on the entire community. The structure of the informal political structure which is able to affect the workings of the apparatus of the public to express, distribute, 
translate, convert demands, support and issues associated with certain common interests, including political parties, interest groups, the media, opinion leaders, and so forth.

In society especially in the political system is certainly a lot of various interests. This should be brokered by the state in order to find a point that can be used as a solution. Then insfrakstruktur politics can be a solution of the problem through the presence of political party as a mouthpiece for the diverse interests that exist.

the success of education providers run by the achievement of the objectives of the state, because the purpose of the state became the main target in the implementation of education, then all the measures taken by the government should not be deviated from the purpose of the state.

The connection between education and politics very closely even always associated that with these circumstances can be seen that the political state was instrumental to determine the direction of the development of education in a country. that the Government made so many policies and amendments to improve the standard of education. The government is so strict in implementing policies and new amendments. The application of the analysis of the political settlement can help to explain patterns of progress in access and quality of education, and to identify the political incentives underlying it.

Not exaggerating that education as one effort or means to preserve the power of the state. Politics is policy, who is the master of politics or who becomes the leader it was he who then determine the direction of education. Politics in the National Education System in Indonesia is also effect on the education budget. Funding of Education as mentioned in Article 31 paragraph (4) of the 1945 constitution that the State budget prioritizes education to at least $20 \%$ of APBN/APBD with the reality and practice of education funding. Fact that the budget of education by $20 \%$ state budget local budget is used for various educational purposes, including the budget for teachers ' welfare, thus causing a very limited budget it is not maximum utilization. It is motivated by a political government that is not healthy. Supposedly, the politics in the government is able to facilitate the public interest, especially in the field of education. Through education, the younger generation should be given the planting of knowledge of economic science, economic issues, to the solution to the economic problems.

\section{METHODS}

This research is a study of literature by analyzing the sources of literature related to the concept of a basic economic education at the level of the supra-structure and infra-political structure in Indonesia. This research was conducted against the results of the research, books, libraries, documents or information-the information contained in the internet. The Data collected in this study were analyzed qualitatively by considering the purpose of the study. 


\section{RESULT AND DISCUSSION}

Based on the analysis of researchers studies about the concept of the economic policy of the education at the level of supra-structure and infra-political structure in Indonesia, it's already done effort in the improvement of the quality of education in Indonesia. Decentralization, the government has estimated the funding for education by $20 \%$. In support of education in Indonesia, the government is still evaluated less maximum attention in the field of education compared with the attention of the government towards the other, where education get an estimate that is smaller. Not just problems estimated to be a factor inhibiting the increasing the quality of education in Indonesia, but still there is a factor of the other. So, it takes a new policy that is more effective in the finish problematika education in Indonesia.

The statement on the line with Mujianto Solichin that education in Indonesia needs to be reform, well connected with the expansion, dissemination, diseminasi, planning the adoption and application of the policy of education in the unit of a particular education. The role of education in a Country is very vital, because quality education will produce the human resources that are qualified to be able to get rid of dullness and poverty in a particular Country the Country of Indonesia.

David L. Weakliem also have the same view about the importance of education, he posited that education should get more attention from the government, with the aim to increase economic growth in a country Investment in education will be making the most of development in the future and become a mature and technically can contribute greatly in economic growth will eventually create a welfare society. Professionals from the educational outcomes will create positive conditions including:

1. Motivation of workers is so high that will cause productivity to rise.

2. In the line of duty, do not need the guidance of a prolonged.

3. Improve efficiency in the use of working time.

4. Delegation of authority will be running, so that the leadership can develop thinking that is more global.

The results of this study support the results of previous research, such as David L. Weakliem(2002), Mujianto Solichin and Muhammad Fahmi Hidayatullah, who argued that each nation must prioritize education than from the other sector, because quality education will be able to produce qualified human resources as well. So that will have an impact on the welfare of the community and in line with it, will be able to improve the economy and development in a Country especially for the Country of Indonesia.

\section{CONCLUSION}

From the description above, it can be concluded that economic education is a blend of the two concepts are aligned, namely the economy and education. Principle in the study of economics is efficiency, so that whatever activity is followed by the expenditure of funds must have great benefits. Thus the study of economic welfareoriented, he lived the high society throughout life. Education is an investment in the 
development of the country. Investment in education will be making the most of development in the future and become a mature and technically can contribute greatly in economic growth will eventually create a welfare society.

The elements of the state structure, namely the supra-structure and infra structure is the center-the center of power of the state. The structure of the state is centered on the second element of the organizational structure of the country. Supra state structures is central to the formal power of the state. Formally, the power of the state in the sector of the supra structure centered on the state institutions or organs of the state such as: the legislative, executive, judicial, and other state institutions. While the infra structure of the country is the center of political power of the people. The political power of the people sector infrastructure (building below) contained in the elements of social organization, political figures, community leaders, the tools of political communication, and especially a political organization or a political party The connection between education and politics very closely even always associated that with these circumstances can be seen that the political state was instrumental to determine the direction of the development of education in a Country and in line with it will affect the economic growth impact on the development of a Country.

\section{REFERENCES}

[1] Agus Irianto, Pendidikan Sebagai Investasi Dalam Pembangunan Suatu Bangsa, (Jakarta: Kencana, 2017)

[2] Barna Subarna, Pendidikan Gratis Sekolah Pertama Antara Harapan dan Kenyataan, (Yogyakarta: Deepublish, 2014)

[3] Budi Winarno, Sistem Politik Indonesia Era Reformasi, (Yogyakarta: Media Pressindo, 2007)

[4] David L. Weakliem, The Effects of Education on Political Opinions:An International Study, International Journal of Public Opinion Research, Volume 14, Issue 2, 1 June 2002. https://doi.org/10.1093/ijpor/14.2.141

[5] Franaois Audigier, Basic Concepts and Core Competencies for Education for Democratic Citizenship, (Switzerland: University of Geneva, 2000)

[6] Hansen, W. Lee; And Others, Master Curriculum Guide in Economics for the Nation's Schools. Part I, A Framework for Teaching Economics: Basic Concepts. https://eric.ed.gov/?id=ED148648

[7] Irjus Indrawan, Konsep Dasar Ekonomi Pendidikan pada Tataran Suprastruktur dan Infrastruktur Politik di Indonesia, Journal For Religious-Innovation Studies Vol.XIX No.1 January-June 2019 p.91-98, https://innovatio.pasca.uinjambi.ac.id/index.php/INNOVATIO/article/view/80

[8] Johan Jasin, Hukum Tata Negara Suatu Pengantar, (Yogyakarta: Deepublish, 2016)

[9] Muhammad Fahmi Hidayatullah, Reintegrasi Pendidikan Indonesia melalui pemikiran dan gerakan Fethullah Gulen, Qolamuna Jurnal Studi Islam, Vol. 6 No. 2, 2021, https://stismu.ac.id/ejournal/ojs/index.php/qolamuna/article/view/218 
[10] Mujianto Solichin, Implementasi Kebijakan Pendidikan dan Peran Birokrasi, Religi Jurnal Studi Islam Vol.6. No 2. 2015.

http://journal.unipdu.ac.id/index.php/religi/article/view/486

[11] Philippe Aghion, Peter W.Howitt, The Economics of Growth, (England: Massachusetts Institute of Technology, 2009)

[12] Soetrisno, Kapita Selekta Ekonomi Indonesia, (Yogyakarta: Andi Offset, 1992)

[13] Syafi'I, Politik Pendidikan Agama di Sekolah,(Jakarta: Young Progressive Muslim, 2020) 